\section{LA-UR-}

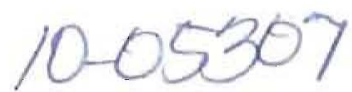

Approved for public release: distribution is unlimited.

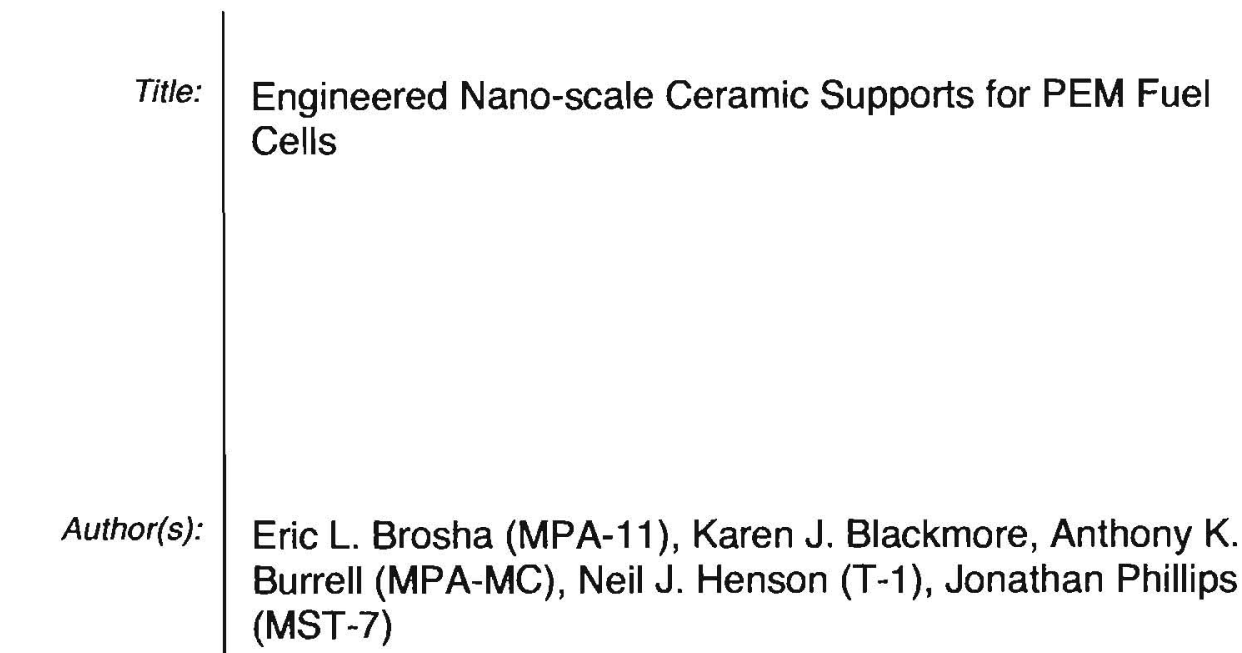

Intended for

2010 Fuel Cell Seminar and Exposition

San Antonio, TX

October $25-29,2010$

Los Alamos National Laboralory, an affirmative action/equal opportunlty employer, is operated by the Los Alamos National Security, LLC for the National Nuclear Security Administration of the U.S. Department of Energy under contract DE-AC52-06NA25396. By acceptance of this article, the publisher recognizes that the U.S. Government retains a nonexclusive, royalty-free license to publish or reproduce the published form of this contribution, or to allow others to do so, for U.S. Government purposes. Los Alamos National Laboratory requests that the publisher identify this article as work performed under the auspices of the U.S. Department of Energy. Los Alamos National Laboratory strongly supports academic freedom and a researcher's right to publish; as an institution, however, the Laboratory does not endorse the vlewpoint of a publication or guarantee its lechnical correctness.

Form $836(7 / 06)$ 


\title{
Engineered Nano-scale Ceramic Supports for PEM Fuel Cells
}

\author{
Eric L. Brosha ${ }^{1}$, Karen J. Blackmore ${ }^{1}$, Anthony K. Burrell ${ }^{1}$, Neil J. Henson ${ }^{1}$, Jonathan \\ Phillips ${ }^{1}$ \\ ${ }^{1}$ Los Alamos National Laboratory \\ MS D429, P.0. Box 1663 \\ Los Alamos, NM 87545 \\ Phone: (505) 665-4008; Fax (505) 665-4292 \\ E-mail: brosha@lanl.gov
}

\section{Introduction}

Catalyst support durability is currently a technical barrier for commercialization of polymer electrolyte membrane (PEM) fuel cells, especially for transportation applications. Degradation and corrosion of the conventional carbon supports leads to losses in active catalyst surface area and, consequently, reduced performance. As a result, the major aim of this work is to develop support materials that interact strongly with Pt, yet sustain bulk-like catalytic activities with very highly dispersed particles. This latter aspect is key to attaining the 2015 DOE technical targets for platinum group metal (PGM) loadings $\left[0.20 \mathrm{mg} / \mathrm{cm}^{2}\right.$ ).

The benefits of the use of carbon-supported catalysts to drastically reduce Pt loadings from the early, conventional Pt-black technology [1-4] are well known. The supported platinum catalyzed membrane approach widely used today for fabrication of membrane electrode assemblies (MEAs) was developed shortly thereafter these early reports [5-7]. Of direct relevance to this present work, are the investigations into Pt particle growth in PEM fuel cells [8], and subsequent follow-on work showing evidence of Pt particles suspended free of the support within the catalyst layer [9]. Further, durability work has demonstrated the detrimental effects of potential cycling on carbon corrosion [10-14] and the link between electrochemical surface area and particle growth [15].

To avoid the issues with carbon degradation altogether, it has been proposed by numerous fuel cell research groups to replace carbon supports with conductive materials that are ceramic in nature [16, 17, and references therein]. Intrinsically, these many conductive oxides, carbides, and nitrides possess the prerequisite electronic conductivity required, and offer corrosion resistance in PEMFC environments; however, most reports indicate that obtaining sufficient surface area remains a significant barrier to obtaining desirable fuel cell performance. Ceramic materials that exhibit high electrical conductivity and necessary stability under fuel cell conditions must also exhibit high surface area as a necessary adjunct to obtaining high Pt dispersions and Pt utilization targets. Our goal in this work is to identify new synthesis approaches together with materials that will lead to ceramic supports with high surface areas and high Pt dispersions. Several strong candidates for use as PEMFC catalyst supports include: transition metal nitrides and substoichiometric titanium oxides, which hither to now have been prepared by other researcher groups with relatively low surface areas (ca. $1-50 \mathrm{~m}^{2} / \mathrm{g}$ typical [16-18]).

To achieve our goals of engineering high surface area, conductive ceramic support for utilization in PEMFCs, a multi-institutional and multi-disciplinary team with experience synthesizing and investigating these materials has been assembled. This team is headed by Los Alamos National Laboratory and includes Oak Ridge National Laboratory and the University of New Mexico. This report describes our fiscal year 2010 technical progress related to applying advanced synthetic methods towards the development of new ceramic 
supports for Pt catalysts for PEM fuel cells.

\section{Approach}

Our approach to preparing ceramic powders with prerequisite properties for use as a PEMFC Pt catalyst support is centered on the application of several novel materials synthesis methods. The first synthesis method used in this work is the aerosol through plasma (A-T-P) process. In this method, largely developed at LANL, a gas or liquid aerosol containing precursor species is passed through the hot zone ( $\mathrm{T}>3500 \mathrm{~K}$ ) of plasma (virtually any gas including Ar, oxygen, nitrogen, air) with a residence time of the order of 0.1 second. The particles, modified by the plasma, then enter a zone of rapid cooling $(105 \mathrm{~K} / \mathrm{s}$ or more) where nucleation and growth of new structures generally takes place. A particularly relevant example of the capability of the process was the production of supported metal particles. We are also employing a new materials synthesis process called polymer assisted deposition (PAD) that was developed at LANL. This is a solution method for the formation of materials ranging from oxides to nitrides and oxynitrides.

Computational methods will be used to complement the experimental effort. Initially, computational studies have been carried out to understand the structure and stability of the support materials in the absence of platinum particles. Following this, the parameters may then be used to study the nature of the platinum binding sites on the support and the platinum adhesion energy, the mobility of platinum on the support and the interplay between the electronic structure of the support and the platinum particle, which is reflected in the calculated density of states. Comparison of these values with bulk platinum can be used as a predictive tool for the optimization of the material.

\section{Results}

The use of the polymer assisted deposition (PAD) process has been successful at producing conductive ceramic materials with high surface areas. High Surface area, conductive foams were successfully synthesized for molybdenum as $\mathrm{Mo}_{2} \mathrm{~N}$. Figure 1 shows the XRD pattern obtained for $\mathrm{Mo}_{2} \mathrm{~N}$ sample final anneal temperature of $950^{\circ} \mathrm{C}$ in $6 \% \mathrm{H}_{2} / \mathrm{Ar}$. is the data has been fit to a cubic crystal structure (indices indicated) with a lattice parameter calculated to be $4.268 \AA$. Full profile fitting of the diffraction data indicates an average crystallite size of $1.6 \mathrm{~nm}$. The BET surface area for this sample was approximately $500 \mathrm{~m}^{2} / \mathrm{g}$. This is an exceptionally high surface area for a transition metal nitride powder. TEM analysis performed by ORNL also indicate highly crystalline structures on the order of $2 \mathrm{~nm}$ with 0.2 to $2 \mu \mathrm{m}$ agglomerates comprised of carbonaceous material holding together the smaller crystallites. Samples prepared using the PAD process typically show broad, amorphous diffraction characteristics ca. $26^{\circ}$ two-theta and this would be explained by the presence of carbon. The exact weight percentage of carbon in these samples is presently being determined. Also to be determined is whether the residual carbon is only present in between $\mathrm{Mo}_{2} \mathrm{~N}$ particles or whether it is in solution with the moly-nitride. $\mathrm{Mo}_{2} \mathrm{~N}$ samples have also been prepared at $700^{\circ} \mathrm{C}$ with slightly higher surface area and a smaller average crystallite size on the order of $1 \mathrm{~nm}$. A glassy carbon electrode $(0.5 \mathrm{~cm}$ dia.) was prepared using a $1 \mathrm{mg} / \mathrm{ml}$ suspension of the as-synthesized $\mathrm{Mo}_{2} \mathrm{~N}$ (both 700 and $950^{\circ} \mathrm{C}$ preparation temperatures) after grinding the sample in an alumina mortar with isopropyl alcohol. Initial $\mathrm{CV}$ characterization (in $0.5 \mathrm{M} \mathrm{H}_{2} \mathrm{SO}_{4}$ ) showed no Faradic activity when the voltage was changed at a sweep rate of $100 \mathrm{mV} / \mathrm{s}$ from 0 to $1.2 \mathrm{~V}$ using a hydrogen reference electrode with $6 \% \mathrm{H}_{2}$ forming gas. The rotating disk electrode experiment $\left(0.5 \mathrm{M} \mathrm{H}_{2} \mathrm{SO}_{4}\right.$ saturated with 
$\mathrm{O}_{2}$ ) did not show any oxygen reduction activity.

Figure 2 is the XRD pattern obtained after Pt disposition $(20 \mathrm{wt} \%)$ onto the $700^{\circ} \mathrm{C}$ prepared $\mathrm{Mo}_{2} \mathrm{~N}$ using incipient wetness approach and hexachloroplatinic acid post reduction. The $\mathrm{Mo}_{2} \mathrm{~N}$ sample prepared at $950^{\circ} \mathrm{C}$ was treated to a similar Pt disposition with the same loading with similar XRD but with slightly larger average Pt crystallite sizes. The dried samples were placed into a tube furnace and annealed at $70^{\circ} \mathrm{C}$ for 12 hours to reduce the platinum salt. Full profile analysis of these data indicates an average Pt crystallite size of $36 \AA$. Two new suspensions were prepared using the $\mathrm{Pt} / \mathrm{Mo}_{2} \mathrm{~N}$ catalysts. The catalyst samples were applied to two glassy carbon electrodes $(0.5 \mathrm{~cm}$ dia.) at two different $\mathrm{Pt}$ loadings: $30.6 \mu \mathrm{g} \mathrm{Pt} / \mathrm{cm}^{2}$ for the sample prepared with the $950^{\circ} \mathrm{C}$ annealed $\mathrm{Mo}_{2} \mathrm{~N}$ and $20.4 \mu \mathrm{g}$ $\mathrm{Pt} / \mathrm{cm}^{2}$ for the sample prepared with the $700^{\circ} \mathrm{C}$ annealed $\mathrm{Mo}_{2} \mathrm{~N}$ sample.

Figure 3(a-left) shows the CVs of these catalyst samples. In both experiments, the conditions were identical: $0.5 \mathrm{M} \mathrm{H}_{2} \mathrm{SO}_{4}$ saturated with Ar with voltage scanned at a rate of $100 \mathrm{mV} / \mathrm{S}$ for 8 cycles each. The CVs shows hydrogen activity similar to Pt/XC-72 carbon with an apparent reversible oxidation peak at $0.45 \mathrm{~V}$ and reduction peak at $0.4 \mathrm{~V}$. It is interesting that both CVS show similar activity despite different Pt loadings. This would tend to suggest that more work must be done to better optimize and utilize the Pt. Although the nature of the redox couple at potentials beyond the features well known to hydrogen redox reactions have not been explained, integration of the area under the anodic peak (up to $0.6 \mathrm{~V}$ ) yields an electrochemical active surface area values of $9.8 \mathrm{~m}^{2} / \mathrm{g}_{\mathrm{Pt}}$ and $20.8 \mathrm{~m}^{2} / \mathrm{g}_{\mathrm{Pt}}$ for the platinized $\mathrm{Mo}_{2} \mathrm{~N}$ prepared at 950 and $700^{\circ} \mathrm{C}$, respectively. These particular values for EASA serve as a reference mark and an upper bound only. In our near term future work, we will probe these features and calculate a more accurate EASA for these materials. The $\mathrm{Ar}$ was removed from the electrolyte and it was replaced with $\mathrm{O}_{2}$. The disk electrode was rotated between 400 and $1600 \mathrm{rpm}$ and the $\mathrm{CV}$ characterization was performed at a scan rate of $20 \mathrm{mV} / \mathrm{s}$. Figure 3 (b-right) shows the results for oxygen reduction activity for the $\mathrm{Mo}_{2} \mathrm{~N}$ sample prepared at $950^{\circ} \mathrm{C}$ and at a loading of $30.6 \mu \mathrm{g} \mathrm{Pt} / \mathrm{cm}^{2} 950^{\circ} \mathrm{C}$. As with the hydrogen $\mathrm{CVs}$, the $\mathrm{Mo}_{2} \mathrm{~N}$ sample prepared at the lower temperature, $700^{\circ} \mathrm{C}$, and at a lower

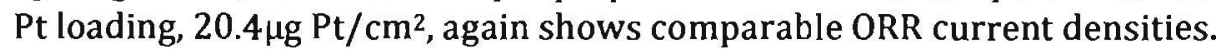

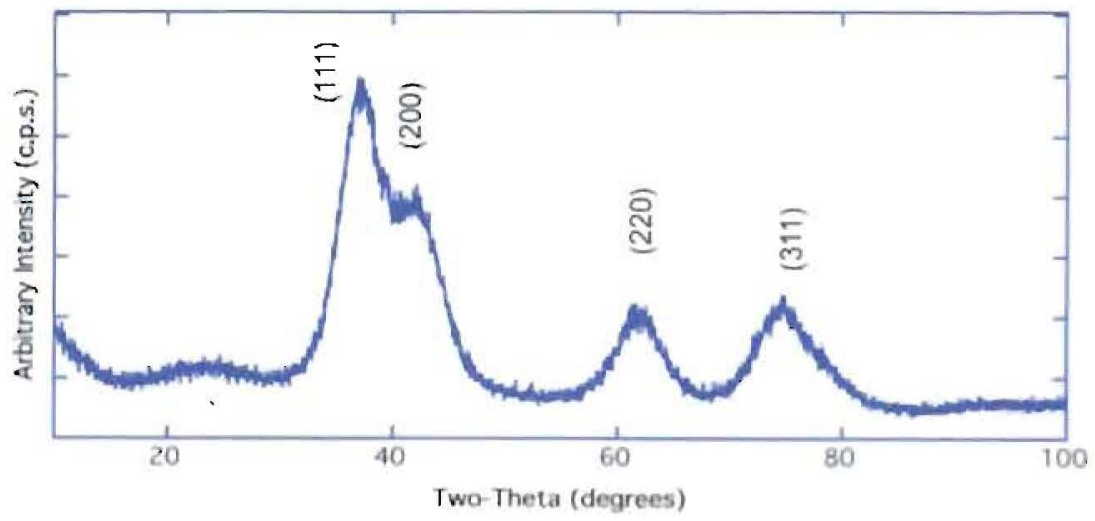

Figure 1. XRD trace from 10 to $100^{\circ}$ degrees two-theta of a $\mathrm{Mo}_{2} \mathrm{~N}$ sample prepared at $950^{\circ} \mathrm{C}$ using the LANL PAD process. Unit cell indices are indicated. Full profile fitting to a primitive cubic cell, $a=4.268 \AA$. Average crystallite size from profile fitting data is $16 \AA$. 


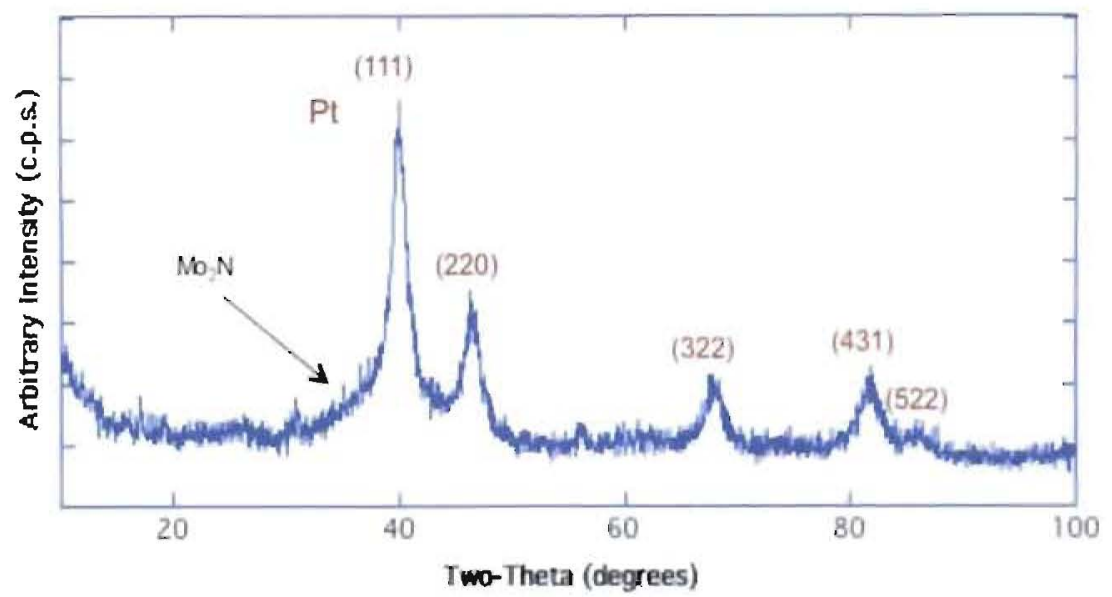

Figure 2. XRD trace from 10 to $100^{\circ}$ degrees two-theta of a $\mathrm{Mo}_{2} \mathrm{~N}$ sample prepared at $700^{\circ} \mathrm{C}$ after $\mathrm{Pt}$ disposition (20wt\%) and subsequent anneal for $12 \mathrm{hrs}$ at $70^{\circ} \mathrm{C}$ in $6 \% \mathrm{H}_{2}$. Unit cell indices for Pt are indicated. Full profile fitting of the support and Pt yield an average Pt crystallite size of $36 \AA$.
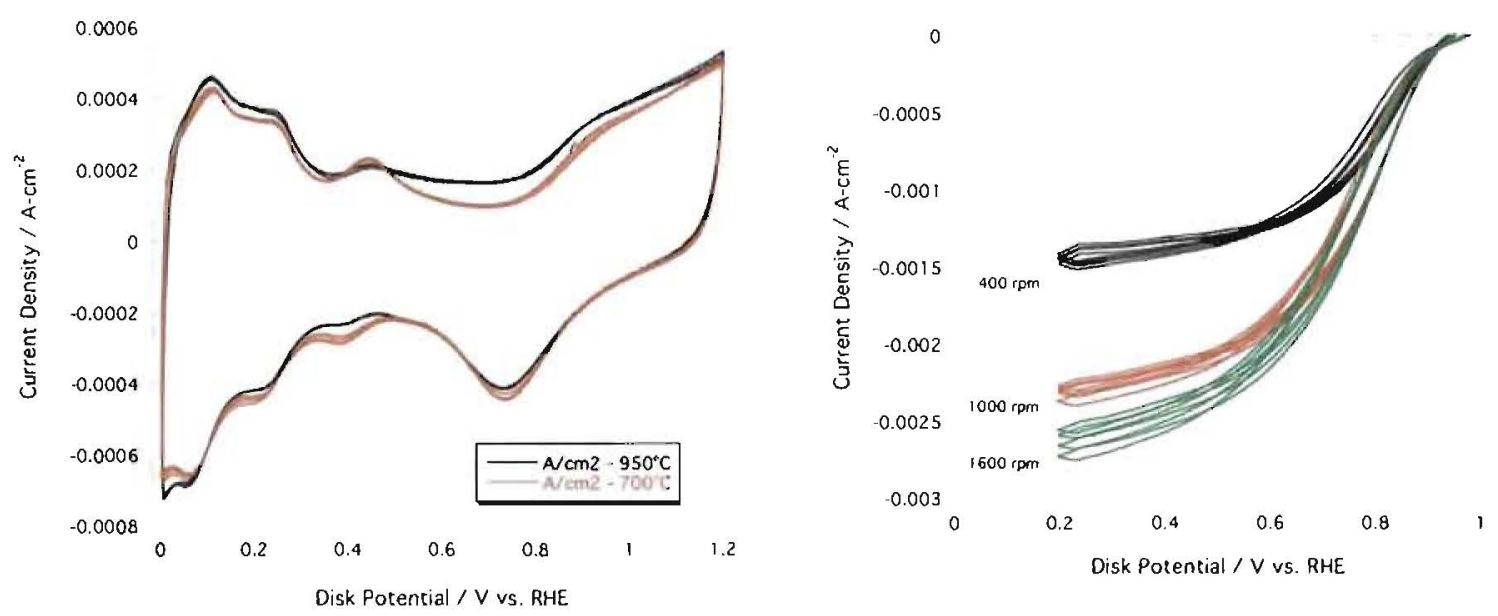

Figure 3. (a-Left) $\mathrm{CV}$ characterization of platinized $\mathrm{Mo}_{2} \mathrm{~N}$ samples prepared at 700 and $950^{\circ} \mathrm{C}$ using the PAD process. Pt loadings are $20.4 \mu \mathrm{gt} / \mathrm{cm}^{2}$ and $30.6 \mu \mathrm{g} \mathrm{Pt} / \mathrm{cm}^{2}$ respectively $\left(0.5 \mathrm{M} \mathrm{H}_{2} \mathrm{SO}_{4}, 100\right.$ $\mathrm{mV} / \mathrm{s}$ ). (b-right) $\mathrm{RDE}$ characterization of platinized $\mathrm{Mo}_{2} \mathrm{~N}$ samples prepared at $950^{\circ} \mathrm{C}$ using the $\mathrm{PAD}$ process. Pt loading is $30.6 \mu \mathrm{gt} / \mathrm{cm}^{2}\left(0.5 \mathrm{M} \mathrm{H}_{2} \mathrm{SO}_{4}, 100 \mathrm{mV} / \mathrm{s}\right)$.

High surface area, conductive foams were successfully synthesized for titanium as both TiO and $\mathrm{TiO}_{2-n}$ using a modified PAD process. In the case of titanium oxide materials, the variation of the flow rate and purge time determine the extent of oxygen reduction. This important control parameter is presently being studied in greater detail and will be greatly expanded upon in future reports. As of preparation of this report, high surface area, black titanium oxide foams have been prepared using the PAD approach. The black color is highly indicative $\mathrm{TiO}_{2-x}$ with $0<x \leq 1$. The two-point resistance of a typical piece of foam (ca. 1 c.c. in approximate volume) was similar to that of the $\mathrm{Mo}_{2} \mathrm{~N}$ foams; e.g. on the order of $10 \mathrm{ohms}$. The initial BET surface area measurements performed on the first samples of black titania powders confirm gas accessible surface areas similar to Vulcan XC-72 (e.g. $200-250 \mathrm{~m}^{2} / \mathrm{g}$ ). These surface areas are significantly higher than commercial, conductive Magneli phase $\mathrm{Ti}_{4} \mathrm{O}_{7}$ synthesized through bulk synthesis and reduction (ca. 1-2 $\mathrm{m}^{2} / \mathrm{g}$ ) or even through 
hydrogen reduction of nano-crystalline anatase or rutile $\mathrm{TiO}_{2}$ powders (ca. $25-50 \mathrm{~m}_{2} / \mathrm{g}$ ) $[16,17]$. We have started structural characterization of these recently prepared titania supports.

Computational studies of ceramic support candidates commenced recently to provide theoretical input to experimental work. Periodic density functional calculations were carried out using the VASP software on three bulk molybdenum nitride polymorphs (rhombohedral $\partial-\mathrm{MoN}$, tetragonal $\beta-\mathrm{Mo}_{16} \mathrm{~N}_{7}$, and cubic $\gamma$-MoN). These calculations provide a calibration for the quantum chemical method used via a comparison of the experimental and calculated structural parameters. The calculations reproduce the crystal structure data to within $4 \%$, confirming the valid of the computational approach. The simplest surface structure was then selected as a model for the catalyst substrate $\{(001)$ surface of $\partial-\mathrm{MoN}\}$ and a geometry optimization calculation was performed to examine the effects of surface relaxation compared to the bulk structure. Using this structure, the effects of surface adhesion of platinum were investigated. Three platinum binding sites on the MoN surface were considered: the on-top site, a bridging site and a three-fold binding site. The calculated binding energies for each of the sites was found to decrease in the order: threefold $\sim$ bridging $\gg$ on-top. The binding energy for the three-fold site is calculated to be comparable to that of a single platinum atom on a $\operatorname{Pt}(111)$ surface (approximately 550 $\mathrm{k}] \mathrm{mol}^{-1}$ ). The bulk structures of three Mo-N phases (tetragonal $\beta$, rhombohedral $\partial$, and cubic y) were calculated with excellent agreement to literature data. The simplest surface structure $(\partial-\mathrm{MoN})$ was then selected, a model created, and the relative binding energies for the three possible Pt sites were calculated. The results were obtained plane wave DFT with VASP software from calculations of the same class used to obtain the parent molybdenum nitride structures.

\section{References}

1. I.D. Raistrick in J.W. Van Zee, R.E. White, K. Kinoshita and H.S. Burney (Eds.), "Proceedings of the Symposium on Diaphragms, Separators, and Ion Exchange Membranes," The Electrochemical Society, (1986) p.172.

2. I.D. Raistrick, 'Electrode Assembly for Use in a Polymer Electrolyte Fuel Cell,' U.S. Patent No. 4,876,115 (1989).

3. E.A. Tícianelli, C. R. Derouin and S. Srinivasan, "Localization of Platinum in Low Catalyst Loading Electrodes to Attain High-power Densities in SPE Fuel Cells," J. Electroanal. Chem. 251 (1988) 275.

4. E.A. Ticianelli, C.R. Derouin, A. Redondo and S. Srinivasan, "Methods to Attain High-Power Densities in Solid-Polymer Electrolyte Fuel-Cells using Low Platinum Loading Electrodes," J. Electrochem. Soc. 135 (1988) 2209.

5. M.S. Wilson, 'Membrane Catalyst Layer for Fuel Cells,' US Patent No. 5,234,777. August 10, 1993.

6. M.S. Wilson and S. Gottesfeld, "High-Performance Catalyzed Membranes of Ultra-Low Pt Loadings for Polymer Electrolyte [-uel-Cells," J. Electrochem. Soc. 139 (1992) L28-30.

7. M.S. Wilson and S. Gottesfeld, "Thin-Film Catalyst Layers for Polymer Electrolyte Fuel-Cell Electrodes," J. Appl. Electrochem. 22 (1992) 1-7.

8. M.S. Wilson, F. H. Garzon, K. E. Sickafus, S Gottesfeld, S., “Modeling and Experimental Diagnostics in Polymer Electrolyte Fuel Cells," J. Electrochem. Soc., 140 (10) (1993) 2872-2877.

9. Karren L. More, 2005 DOE annual report

10. R. Borup, J.R. Davey, F.H. Garzon, D. L, Wood, and M. A. Inbody, "PEM fuel cell electrocatalyst durability measurements," J. Power Sources 163 (1) 76 (2006).

11. R. Borup, F. H. Garzon, D. L. Wood, J. R. Davey and E. L. Brosha, "PEM Electrode Durability Measurements," Presented at Electrochemical Society, Second International Conference on Polymer Batteries and Fuel Cells, Las Vegas, NV, June 12-17, 2005.

12. Bekkedahl, Timothy A.; Bregoli, Lawrence J.; Breault, Richard D.; Dykeman, Emily A.; Meyers, Jeremey P.; Patterson, Timothy W.; Skiba, Tommy; Vargas, Chris; Yang, Deliang Yi, Jung S., US Patent application 20040081866. 
13. F. H. Garzon, J.R. Davey, and R.L. Borup, "Fuel Cell Catalyst Particle Size Growth Characterized by X-ray Scattering Methods," ECS Transactions Vol. 1, iss. 8 (2005) 153-166.

14. R Borup, J. Davey, D. Wood, F. Garzon, M. Inbody, D. Guidry, 2005 DoE Hydrogen Program Review, May $25,2005$.

15. Garzon F.H., Davey I.R., and Borup, R.L. "Fuel Cell Catalyst Particle Size Growth Characterized by X-Ray Scattering Methods," ECS Meeting Abstracts (2005) Vol. MA 2005-02, p.2223.

16. Antolini, E., and Gonzalez, E.R., "Ceramic materials as supports for low-temperature fuel cell catalysts," Solid State Ionics 180 (2009) p. 746.

17. Shao, Y., Liu, J., Wang, Y., and Lin, Y., "Novel catalyst support materials or PEM fuel cells: current status and future prospects,"J. Mat. Chem. 19 (2009) p. 46. 